Acta vet. scand. 1970, 11, 295-304.

From the Department of Medicine, Veterinary College of Norway, Oslo.

\title{
STUDIES OF ELECTROPHORESIS ON CELLULOSE ACETATE MEMBRANE OF SERUM PROTEINS FROM NORMAL HORSES, SHEEP AND PIGS
}

By

Nils $E k$

A report of experiments involving electrophoresis on cellulose acetate membrane of bovine serum proteins has previously been published ( $E k 1969$ ). The present report concerns similar experiments with serum proteins in normal serum from horses, sheep and pigs.

The examination of serum proteins in normal domestic animals with the aid of paper electrophoresis was carried out by Boguth (1954) and has later been performed by a number of other investigators (Stöckl 1954, Irfan 1967 etc.). As far as can be seen from the available literature no reports of experiments using cellulose acetate membrane for the electrophoresis of serum from domestic animals have been presented.

It was the aim of the present experiment to use this technique in order to obtain the best possible separation and, by further experiment, identify the individual main serum fractions. On the diagrams the albumin fraction is marked $A$ and the three main fractions in the globulin part are provisionally marked I, II and III, mentioned in order according to decreasing mobility.

By electrophoretically comparing normal serum with separated material of known composition, an attempt has been made to identify these main fractions and express them in accordance with the nomenclature usually used, as $\alpha$-, $\beta$ - and $\gamma$-globulin respectively. 
The experiment also involved examinations in order to obtain normal values in connection with the percentage composition of the main fractions in the serum of the animal species concerned by using the presented method.

\section{MATERIAL AND METHODS}

Undiluted serum and serum diluted with distilled water $1: 1$ were used from 50 normal horses of the breed "dфle" horse, $3-12$ years old and of both sexes, 30 normal sheep of the breed Norwegian "spel" sheep, ewes, age $1-6$ years, and 30 pigs of the Norwegian land pig breed, age $6-7$ months, of both sexes.

\section{Preparations}

1. $\gamma$-globulin separated from equine serum, ovine serum and porcine serum with DEAE-Sephadex according to the method reported by Baumstark et al. (1964).

2. A mixture of $\gamma$-globulin + transferrin separated from horse serum, sheep serum and pig serum with rivanol according to the method of Patras \& Stone (1961).

The same method was used for the electrophoresis as for the previously reported experiment with bovine serum ( $E k$ 1969), but with modified voltage, $280 \mathrm{v}$, and standard buffer B-2.

In order to test the accuracy of the method, all samples were examined twice. The standard deviations for the relative percentages of the serum protein fractions were calculated according

to the formula: $s=\sqrt{\frac{\Sigma d^{2}}{2 n}}$ in which $d$ is the difference between dublicate determinations and $n$ the number of dublicate analyses. Concerning the 50 dublicate analyses of horse serum given in Table 1, s was for albumin 1.8, $\alpha$-globulin 1.2, $\beta$-globulin 1.3 and $\gamma$-globulin 1.1. The corresponding values for the 30 sheep serum samples were: albumin 2.3, $\alpha$-globulin 1.3, $\beta$-globulin 0.2 and $\gamma$-globulin 1.8 and finally for the 30 pig serum samples: albumin 1.9, $\alpha$-globulin 1.4, $\beta$-globulin 1.9 and $\gamma$-globulin 0.2 .

\section{RESULTS}

\section{Horse}

Undiluted serum was found to give the best results.

The diagram in Fig. 1 shows the separated $\gamma$-globulin, separated $\gamma$-globulin + transferrin in mixture and normal serum 


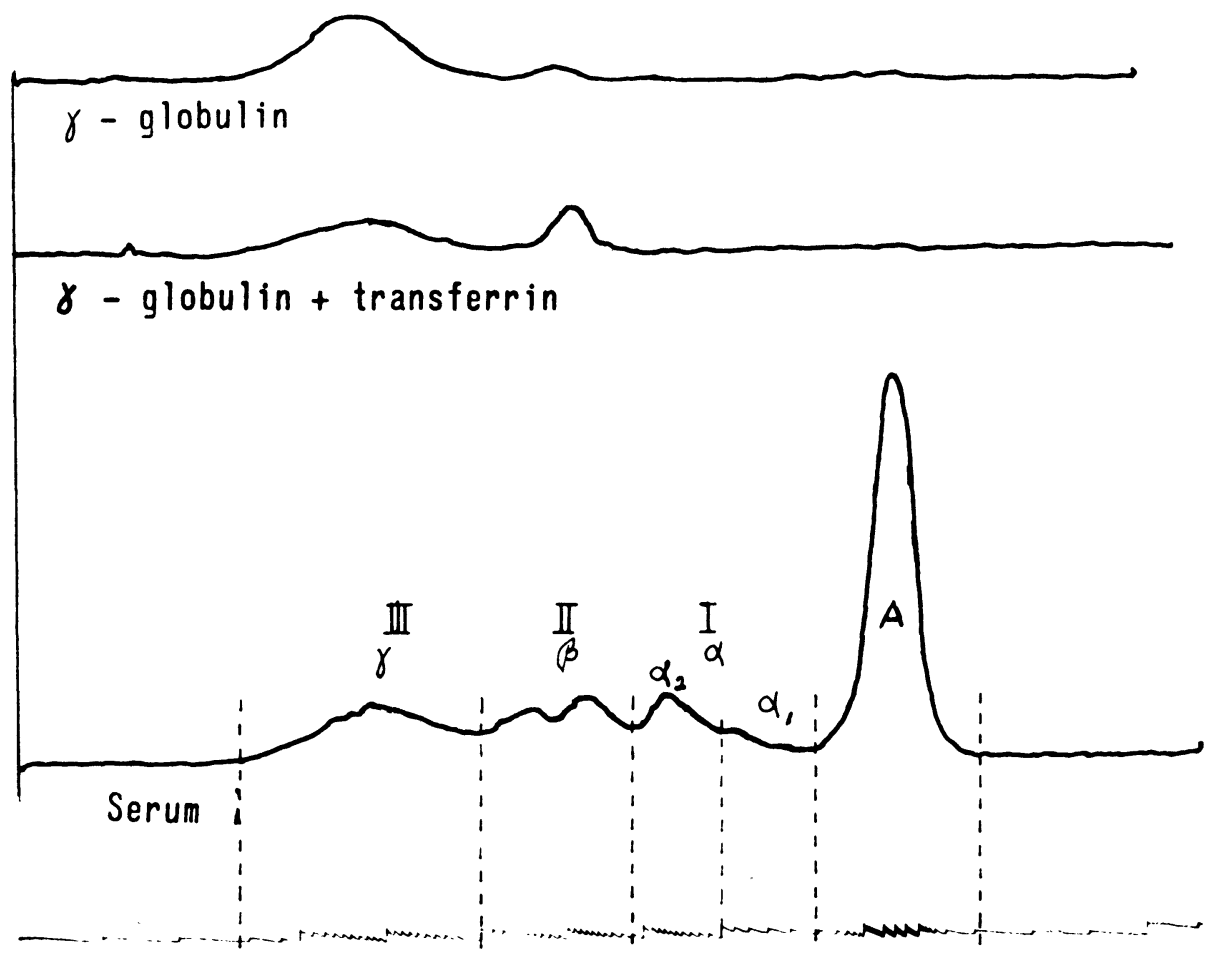

F i gur e 1. Parallel electrophoresis of separated equine $\gamma$-globulin, separated equine $\gamma$-globulin + transferrin in mixture and normal horse serum.

run parallelly. As can be seen, the separated $\gamma$-globulin lies in a zone corresponding to fraction III which consequently must be assumed to be the $\gamma$-globulin component in the serum. One of the two fractions on the middle curve can be seen to lie in the same zone while the other component, which then must be assumed to represent transferrin, lies parallel to fraction II.

In the majority of species transferrin lies electrophoretically in the $\beta$-globulin group, an occurrence which has also been shown in horse serum by Schmid (1962) and Brænd \& Stormont (1964). It thus appears that fraction II is probably $\beta$-globulin and I $\alpha$-globulin.

On the serum curve can be seen a division of the $\alpha$-fraction into a smaller, rapidly moving component and a larger slower part. This was a relatively constant phenomenon with the examined sera. 
In all the examined sera there was a division with the appearance of two peaks in the $\beta$-zone. There were also large individual variations in the shape of the $\beta$-fraction. Of the samples examined, $60 \%$ showed a division in the form of a larger, rapidly moving peak near the $\alpha$-zone and a smaller part near the $\gamma$-zone (see Fig. 1).

Of the remaining serum samples, $20 \%$ had a larger, slow peak near the $\gamma$-zone and a smaller rapidly moving part, while $20 \%$ showed a division into two peaks of almost equal size.

The percentage composition of the serum fractions in the horse, sheep and pig is given in Table 1.

T a b l e 1. Relative percentages of serum-protein fractions in healthy horses, sheep and pigs. The values given are $\bar{x} \pm s$.

\begin{tabular}{|c|c|c|c|c|c|}
\hline \multirow{2}{*}{$\begin{array}{l}\text { No. of } \\
\text { animals }\end{array}$} & \multirow[t]{2}{*}{ Albumin } & \multicolumn{4}{|c|}{ Globulin } \\
\hline & & $\alpha_{1}$ & $\alpha_{2}$ & $\beta$ & $\gamma$ \\
\hline 50 horses & $47.3 \pm 4.0$ & $4.3 \pm 1.1$ & $9.9 \pm 1.9$ & $19.5 \pm 2.9$ & $19.0 \pm 3.3$ \\
\hline 30 sheep & $48.5 \pm 3.2$ & $8.1 \pm 1.3$ & $12.6 \pm 1.7$ & $8.0 \pm 1.5$ & $22.8 \pm 2.0$ \\
\hline 30 pigs & $43.2 \pm 5.2$ & 19.7 & $=2.6$ & $17.4 \pm 1.7$ & $19.7 \pm 3.3$ \\
\hline
\end{tabular}

Sheep

Electrophoresis carried out under the same conditions as were employed with horse serum gave the best results.

The diagram in Fig. 2 shows separated $\gamma$-globulin, separated $\gamma$-globulin + transferrin in mixture and normal serum from sheep run parallelly.

The $\gamma$-globulin zone in the uppermost curve and the corresponding component in the middle curve fall parallel with fraction III on the serum curve which must be assumed to be the $\gamma$-globulin fraction. The transferrin component in the middle curve can be seen to lie between fractions I and II but nearest fraction I. Electrophoretically transferrin in the serum of sheep lies close to the $\alpha$-globulins (Lie 1969). This indicates that fraction II probably is $\beta$-globulin and fraction I $\alpha$-globulin.

In the $\alpha$-globulin fraction there are two clearly isolated components. Furthermore, the serum curve shows that there is a certain division of the $\gamma$-fraction into a smaller, slowly moving part and a larger, more rapidly wandering component. 


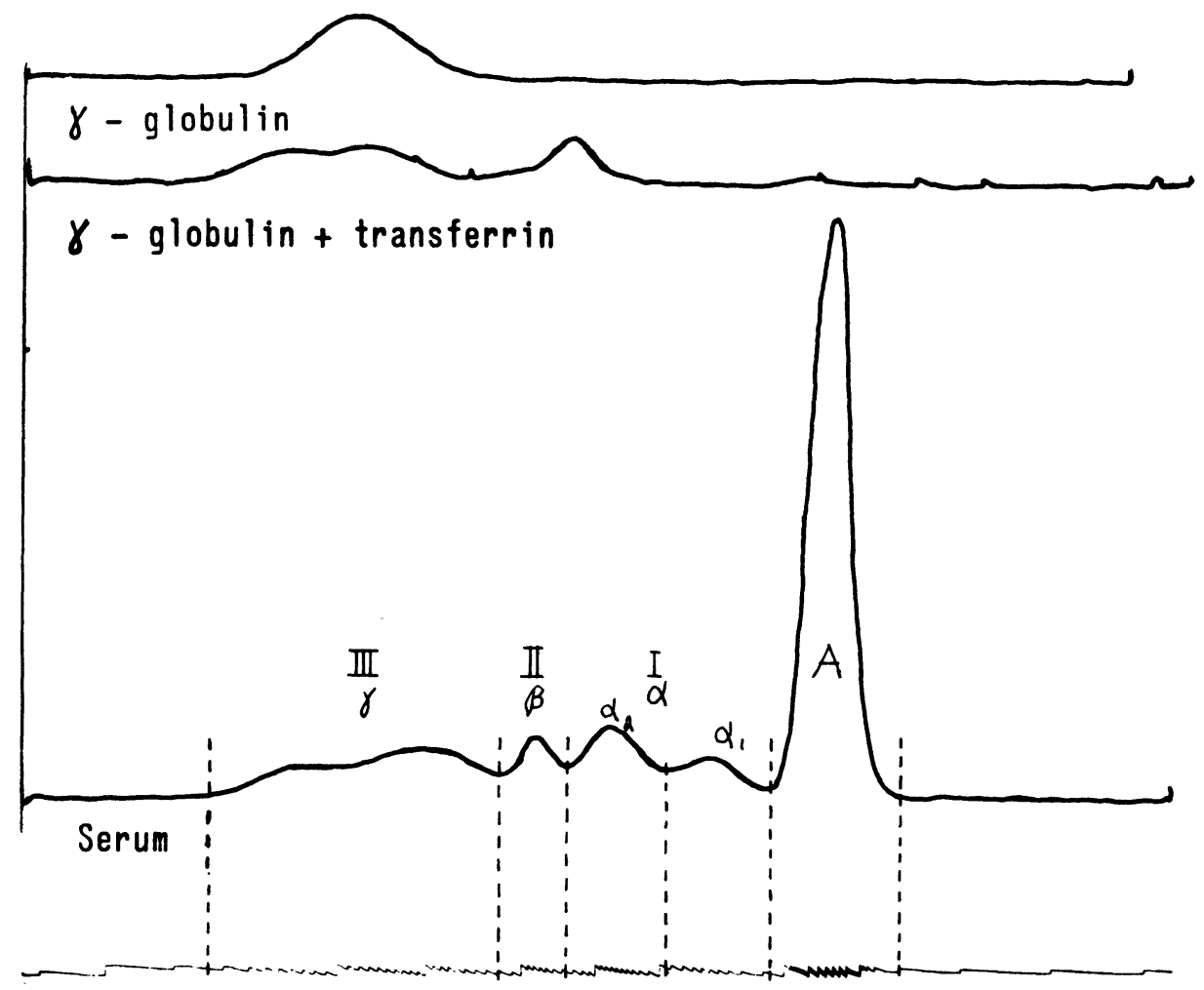

Figure 2. Parallel electrophoresis of separated ovine $\gamma$-globulin, separated ovine $\gamma$-globulin + transferrin in mixture and normal sheep serum.

\section{Pig}

Serum diluted with distilled water $1: 1$ produced better separation than undiluted serum. By using serum in this dilution it was possible to obtain curves where the borders between the various main fractions in the globulin part were lying much nearer the base-line of the diagram.

Fig. 3 shows the two preparations consisting of $\gamma$-globulin and $\gamma$-globulin + transferrin in mixture run parallelly with normal serum from the pig.

As can be seen from the diagram the $\gamma$-globulin zone on the two uppermost curves falls parallel with fraction III on the serum curve, and the transferrin peak on the middle curve lies in the same zone as fraction II. The result of this examination of pig serum was, therefore, three undivided, almost equal-sized main fractions in the globulin part, $\alpha$-, $\beta$ - and $\gamma$-globulin. 


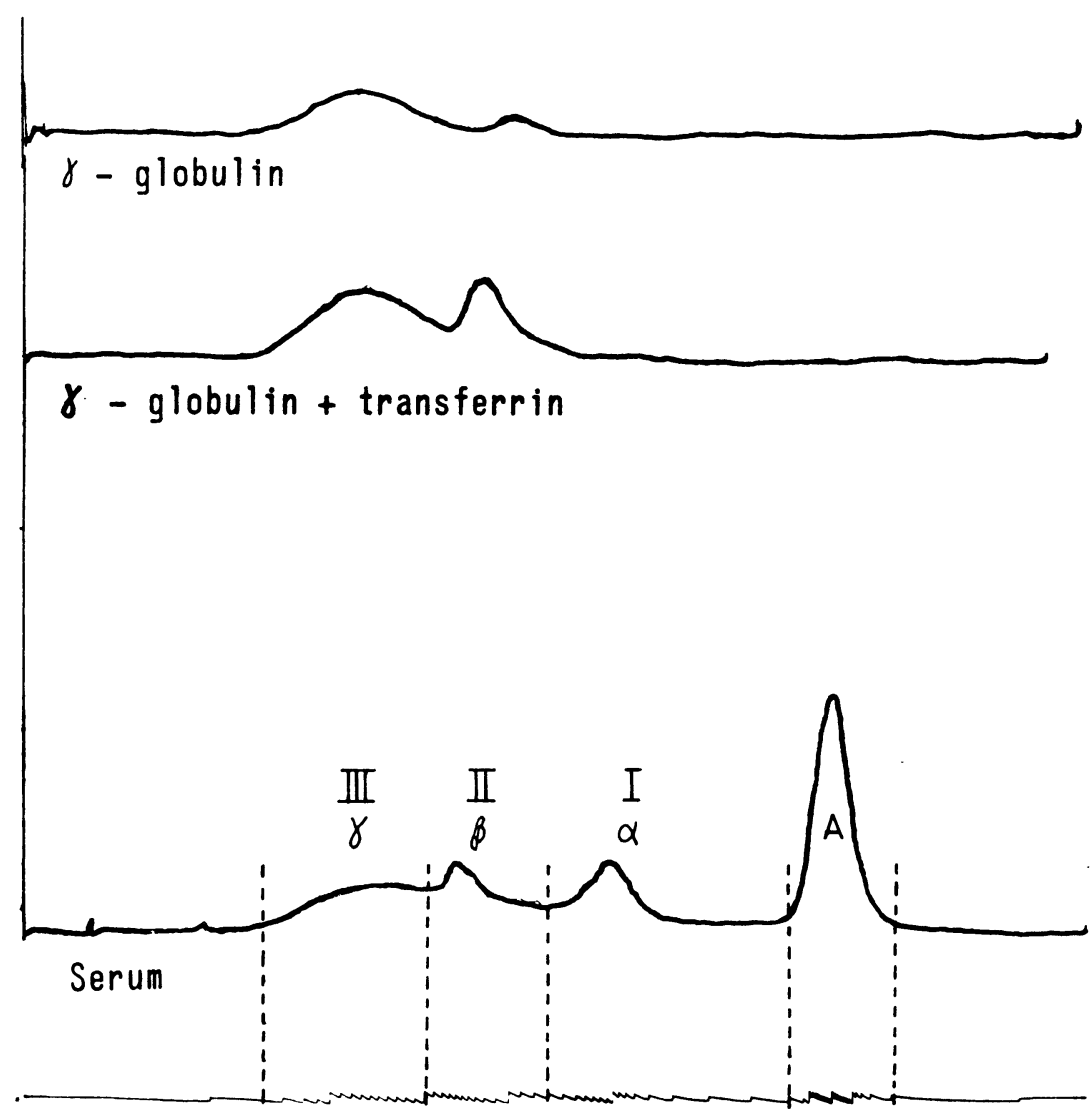

Fig u r e 3. Parallel electrophoresis of separated porcine $\gamma$-globulin, separated porcine $\gamma$-globulin + transferrin in mixture and normal pig serum.

\section{DISCUSSION}

These experiments show that there is considerable variation between the different animal species as far as the electrophoretic movement and percentage composition of the various serum protein fractions are concerned. Each of the animal species will be discussed individually in the following paragraphs.

\section{Horse}

The division of the $\alpha$-fraction into a smaller component, $\alpha_{1}$, and a larger, more slowly moving part, $\alpha_{2}$, agrees well with the results reported when using paper electrophoresis (Boguth 1954, Irfan 1967 etc.). 
There were greater individual variations in the serum protein fractions in the horse than in the other two species, especially as far as the size and shape of the $\beta$-fraction on the graphs are concerned. The standard deviation for the $\beta$-globulin in the material here presented was greater in the horse than in the other animal species. Using paper electrophoresis Deutsch \& Goodloe (1945) and Boguth (1954) found two $\beta$-components in the horse, while Irfan, using the same method, only obtained one $\beta$-fraction. Radtsev (1962) (ref. from Irfan) also found large individual variations in the serum protein of the horse.

Brænd \& Stormont (1964) found 16 different transferrin types in the horse which were assumed to have their hereditary basis in six autosomal alleles. These alleles controlled transferrin types with various speeds, both slow and rapid. The authors found all the homozygote types except one represented in their material.

The reason for greater individual variations in the horse in the $\beta$-zone must be assumed to be connected with the appearance of various transferrin types. The variations in the $\beta$-zone with larger and smaller peaks with different mobilities found in the present material can be explained by the fact that different transferrin types were represented in the examined horse sera.

The percentage composition of the serum fractions in the horse which was found in these experiments agrees in the main with the values found in the literature, obtained with paper electrophoresis (Boguth, Vesselinovitch 1959 etc.). The percentages reported for albumin lie, however, somewhat lower than those found in the present experiment. Irfan found an albumin percentage of 33.5 compared with 47.3 in this work.

\section{Sheep}

The pattern found in the globulin part with two $\alpha$-components, one $\beta$ - and one $\gamma$-fraction was also observed by Irfan. On the curve presented in Fig. 2 there was a tendency of division of the $\gamma$-fraction. Perk \& Lobl (1960) found such a division of the $\gamma$-fraction in mature sheep but not in lambs.

The percentage composition of the serum protein fractions agrees on the whole with the results obtained with paper electrophoresis reported by several authors (Irfan etc.). Vesselinovitch reports a somewhat higher value for $\gamma$-globulin. Perk \& Lobl 
found higher $\gamma$-globulin values in lactating ewes than in rams of the same age, and also a constant increase in $\gamma$-globulin with increasing age.

\section{Pig}

The separation of the globulin part into three approximately equal-sized main components, one $\alpha$-, one $\beta$ - and one $\gamma$-fraction has been reported by several investigators (Pirtle \& Deyoe 1963, Irfan).

The percentage composition of the serum fractions in pig serum reported in Table 1 agrees well with corresponding values obtained by use of paper electrophoresis (Vesselinovitch, Pirtle $\&$ Deyoe). Miller et al. (1961) found that a maximum production of $\gamma$-globulin took place between the age of 2-6 months, and after this age a small variation in the normal pig. The figures in Table 1 should therefore be considered to be representative normal values for mature pigs.

As a general rule the method used here appears to be well suited for clinical diagnostic work in the various animal species. The results obtained cannot, however, indiscriminately be compared with values reported from the use of other methods.

The electrophoretic movement of the serum proteins varies in relation to the technique used for the electrophoresis. At this particular technique, having identified and fixed the various fractions on the graph, standardized normal values are therefore needed, obtained by exactly the same method. In the present report such results are calculated for mature horses, sheep and pigs.

With electrophoresis of serum from new-born and very young animals, curves are obtained that are considerably different from those for mature animals (Boguth). It is, therefore, necessary to obtain special normal values if the method is to be used for these new-born or very young animals.

\section{ACKNOWLEDGMENT}

The author wishes to thank Prof. dr. M. Brænd, at present with the Faculty of Veterinary Science, University College, Nairobi, Kenya and Dr. U. Abildgaard, Dept. IX, Ullevål Hospital, Oslo, Norway, for valuable advice and guidance during the experiment. The author owes them both a great debt of gratitude. 


\section{REFERENGES}

Baumstark, J. S., R. J. Laffin \& W. A. Bardawil: A preparative method for the separation of $7 \mathrm{~S}$ gamma globulin from human serum. Arch. Biochem. 1964, 108, 514-522.

Boguth, W.: Papierelektrophoretische Serumuntersuchungen bei Haussäugetieren. (Paper-electrophoretic serum-examinations in do-mestic mammals). Zbl. Vet.-Med. 1954, 1, 168-187.

Brænd, M. \& C. Stormont: Studies on hemoglobin and transferrin types of horses. Nord. Vet.-Med. 1964, 16, 31-37.

Deutsch, H. F. \& M. B. Goodloe: An electrophoretic survey of various animal plasmas. J. biol. Chem. 1945, 161, 1-20.

$E k, N .:$ Studies on electrophoresis on cellulose acetate membrane of bovine serum proteins in healthy animals. Acta vet. scand. $1969,10,118-126$.

Irfan, M.: The electrophoretic pattern of serum proteins in normal animals. Res. vet. Sci. 1967, 8, 137-142.

Lie, $H_{\text {.: }}$ Personal communications 1969.

Miller, E. R., D. E. Ullrey, I. Ackerman, D. A. Schmidt, J. A. Hoefer \& R. W. Luecke: Swine hematology from birth to maturity. I. Serum proteins. J. Animal Sci. 1961, 20, 31-35.

Patras, B. \& W. H. Stone: Partial purification of cattle serum transferrin using rivanol. Proc. Soc. exp. Biol. (N.Y.) 1961, 107, $861-864$.

Perk, K. \& K. Lobl: Chemical and electrophoretic analysis of normal sheep serum proteins and lipoproteins. Brit. vet. J. 1960, 116, 167-174.

Pirtle, E. C. \& B. L. Deyoe: Electrophoresis from specific-pathogenfree swine. Amer. J. vet. Res. 1963, 24, 762-765.

Radtsev, V. S.: cit. Irfan, M. 1967.

Schmid, D. O.: Über den Serumtransferrin-Polymorphismus bei Pferden. (On serum transferrin polymorphism in horses). Z. Immun.-Forsch. 1962, 124, 219-223.

Stöckl, W.: Immunologische und electrophoretische Serumuntersuchungen zwecks frühzeitiger Feststellung zur Rotlaufserumgewinnung geeigneter Pferde. (Immunological and electrophoretic serum-examinations in order to determine early the suitability of horses for obtaining erysipelas serum). Zbl. Vet.-Med. 1954, $1,330-341$.

Vesselinovitch, S. D.: The analysis of serum proteins of domestic animals by filter-paper electrophoresis. A review. Cornell Vet. $1959,49,82-96$.

\section{SUMMARY}

A method for the rapid electrophoresis on a cellulose acetate membrane of serum proteins from horses, sheep and pigs is discussed.

The various main globulin fractions in the serum of these animals were experimentally identified. 
Normal values for the percentage composition of serum from normal horses, sheep and pigs were calculated.

In the horse there was great individual variation in the shape of the $\beta$-fraction, assumed to be due to different transferrin types. The mean value for $\beta$-globulin of $19.5 \%$ in the horse was higher than for the other two species.

The albumin percentage was highest in the sheep and lowest in the pig, $48.5 \%$ and $43.2 \%$ respectively. The sheep had the highest $\gamma$-globulin percentage, $22.8 \%$, while the horse had the lowest with $19.0 \%$.

Finally the values were compared with corresponding figures reported by other authors and the results discussed.

\section{SAMMENDRAG}

Elektroforese-unders $\varnothing k e l s e r$ på cellulose-acetat-membran av serumproteiner fra normale hester, sauer og griser.

Det omtales en metode til hurtigelektroforese på cellulose-acetatmembran av serumproteiner fra hester, sauer og griser.

De enkelte grøvre globulinfraksjoner i disse dyrearters sera ble eksperimentelt identifisert.

Det ble beregnet normalverdier for den prosentvise sammensetning av serum fra normale hester, sauer og griser.

Hos hest var det store individuelle variasjoner i $\beta$-fraksjonens form, noe som ble antatt å skyldes forskiellige transferrintyper. Middelverdien for $\beta$-globulin hos hest på 19,5\% var større enn hos de to andre dyrearter.

Albuminprosenten var høyest hos sau og lavest hos gris, henholdsvis $48,5 \%$ og $43,2 \%$. Sau hadde høyeste $\gamma$-globulinprosent, $22,8 \%$, mens hest hadde den laveste med $19,0 \%$.

Verdiene ble sluttelig sammenlignet med tilsvarende tall angitt av andre forfattere og resultatene diskutert. 